\title{
Taxpayers Knowledge and Compliance: Evidence from Direct Assessment Tax in Lagos State
}

\author{
Joseph Ishola, Abass Oyeshola Bello*, Lateef Olayiwola Raheed \\ Department of Accountancy, School of Part Time Studies, Lagos State Polytechnic, Ikorodu, Nigeria
}

\begin{abstract}
The research work examines the nexus between Tax Knowledge and Tax Compliance among Taxpayers: Evidence from Direct Assessment in Lagos State. This study adopts the survey research design to elicit responses from selected taxpayers in the Ikeja Lagos State of Nigeria to explore what they perceived as the relationship between tax knowledge and tax compliance regarding tax payment and tax filing of returns. Primary data was collected through a designed questionnaire and was administered using the KaiserMeyer-Olkin test. Cronbach Alpha was also used in establishing the sampling adequacy and reliability of the research instrument. The survey results were collected from 200 respondents in three categories in Lagos State with 190 valid responses, including self-employed, taxpayers in public and private establishments in Ikeja from October to November 2020. The study adopted a judgmental sampling technique. The data extracted from the questionnaires were analyzed using a simple table as descriptive and Pearson Correlation at $1 \%$ Level of Significance as inferential statistics. The findings revealed that the general tax knowledge was significantly related to tax compliance in payment terms $(r=.993, p=0.000)$ and tax compliance in terms of filing of returns $(r=.986, p=0.000)$. thus, the study concluded that there is a positive relationship between tax knowledge and tax compliance.
\end{abstract}

Keywords: Tax, Tax Knowledge, Tax Compliance, Tax Payment, Direct Assessment Tax

JEL Classification: $\mathrm{H} 20, \mathrm{H} 24, \mathrm{H} 26$

Paper Type: Research

* Corresponding author: E-mail: abassbello.ab@gmail.com 


\section{INTRODUCTION}

\subsection{BACKGROUND TO THE STUDY}

Olaoye and Ekundayo (2018) stated that the government is saddled with the responsibilities for providing basic amenities and other social services for its citizens. It is then required that governments source funds from various sources to meet their obligations. Many taxpayers would want to avoid and evade tax payments because they are knowledgeable about taxes. However, tax avoidance and tax evasion are frequently discussed topics on both national and European levels. Cechovsky (2018) revealed that tax avoidance and tax evasions are the two most worrisome tax crimes and related issues that any government or tax authority faces and putting all measures to defeat the abnormalities.

Oloyede, Kupoluy, Oyedokun, and Benjamin (2017) despite all the benefits derived from taxation, as sources of funds utilized by the government for the benefit of the citizenry, it has been observed that only a minority, or few people that pay their taxes in Nigeria and these are the formal actors and those working in formal organizations that have records. The informal sector is mainly under direct assessment but would file their returns when the need arises in Nigeria. Oloyede et al. (2017) postulated that the informal sector activities have been described as undocumented, unrecorded, unprotected, and unregulated by public authorities and confined to marginal activities alone but are notable in profitable manufacturing enterprises. However, every tax is expected to be certain and convenient. By this, it is expected that the scope of taxes should be clear, that is, not arbitrary and easy to be paid. Some taxpayers, especially in the informal sector, would always assert that they are not cleared of Nigeria's tax position. Even when a tax consultant tries to educate them, they tend to navigate their tax discussion and education ways.

\subsection{STATEMENT OF THE PROBLEM}

Chandra (2014) cited that the main problem currently faced by Tax authorities is the low compliance of the people to taxation. This means that people's knowledge about taxes, tax rates, tax payment, tax system, etc., may seem very low. Many people would pursue their tax clearance certificates when the need arises. This is evidence by Lestari (2010), who said another factor that also affects tax revenues is the understanding of taxpayers on the implementation of the self-assessment system in carrying out tax obligations of taxpayers measured based on the understanding of taxpayers on the obligation to calculate, calculate, pay, and report the tax payable.

According to Asrinanda (2018), if the people are better knowledgeable and obedient to tax and tax systems in any country, they will increase local tax revenue. Most tax authorities of the world usually encouraged self-assessment of taxes. This means that every taxpayer is expected to file the returns by determining their tax due to applicable rates, conditions, income, tax knowledge, etc. The taxpayer is responsible for self-determination of his tax obligations and then accurately and timely pay and report the tax (Devano \& Rahayu, 2006)

Since the tax collection and processing system shifts from the official assessment (the process where the tax authority first determine taxes to be paid by taxpayers) to selfassessment (the process whereby taxpayers first determine the taxes to be paid by 
taxpayers) as it is today, then some conditions must be met first, the first condition is the level of knowledge of good enough tax in the community and the high level of honesty in filling and reporting tax. However, unfortunately, these two requirements have not been met. Implementing the system self-assessment is not optimal, so the impact of tax compliance level is still low (Chandra, 2014).

This study was critical. It concentrated efforts to assess tax knowledge on tax compliance regarding tax payment and filings of annual returns in Lagos State. Lagos State, Internal Revenue Service, was seen educating and advertising to taxpayers in Lagos State from time to time. The essence of these was to increase the tax knowledge to ensure tax compliance in the state. It would benefit taxpayers, tax authorities, the government, and the general public. This study's research gap was that it was the first to have been conducted in Lagos State, using the Ordinary Least Square method to test the hypotheses.

\subsection{OBJECTIVES OF THE STUDY}

The main objective of this study is to assess tax knowledge on tax compliance among taxpayers in Lagos State concerning Direct Assessment while the specific objectives are:

a) To assess the relationship between tax knowledge and tax compliance in terms of tax payments in Lagos State.

b) To assess the relationship between tax knowledge and tax compliance for filing tax returns in Lagos State.

\subsection{RESEARCH QUESTIONS}

The questions answered for this study were as follows:

a) Is there any relationship between the level of tax knowledge and tax compliance in terms of tax payment in Lagos State?

b) Is there any relationship between tax knowledge and tax compliance regarding the filing of taxes in Lagos State?

\subsection{RESEARCH HYPOTHESES}

The research hypotheses tested for this study were:

Ho1: There is no relationship between the level of tax knowledge and tax compliance in terms of tax payment in Lagos State.

Ho2: There is no relationship between tax knowledge and tax compliance regarding tax filing of returns in Lagos State.

\section{LITERATURE REVIEW}

\subsection{CONCEPTUAL REVIEW}

\subsubsection{TAX KNOWLEDGE}

The essential factor, which could affect tax compliance is the understanding of taxation. Knowledge requirements for small business owners' tax compliance are relevant, according to Wadesango and Mwandambira (2018). Tax is compulsory money levied on all taxpayers by the government of every state, one of the significant fiscal policies to meet citizens' needs. One of the canons of a sound tax system is that tax must be specific and for the tax to be particular, tax knowledge must be well understood. Fauziati, Minovia, 
Muslim, and Nasrah (2016) posit that tax knowledge, in general, is an understanding of the essential tax policy concepts implemented within a country, while Oladipupo and Obazee (2016) assert that tax knowledge is the level of awareness or sensitivity of the taxpayer to tax legislation according to many things, among other factors formal education influence it. Niemirowski, Wearing, Baldwin, Leonard, and Mobbs (2002) state that the influence of knowledge on compliance behaviour had been proven in various research, whereas Bird (2014) argues that one's knowledge about an object such as tax contains two aspects - the positive and negative vibes. Both of these aspects will determine the attitude of a person. Knowledge is the information known or recognized by someone, defined Bird (2014). Knowledge is something that is known to be associated with the learning process. This learning process is influenced by various factors from within, such as motivation and external factors such as the means of information available and sociocultural circumstances proposed by Bird (2014). The taxpayer's knowledge shows the taxpayer's understanding of tax rules, particularly on income tax.

Asrinanda (2018) stated that taxpayers' knowledge is valuable by taxpayers as vital information in tax actions such as calculating, calculating, paying, and reporting the amount of taxes deposited. The existence of a better quality of knowledge will provide the attitude of fulfilling obligations correctly through the existence of a state taxation system that is considered fair. Therefore, the knowledge of taxation owned by the taxpayer will affect the obedience of the taxpayer itself in carrying out its tax obligations. It will also affect the state's tax revenue if the people already have high tax knowledge. Supriyati and Hayati (2012) indicate that tax knowledge affects taxpayers in paying taxes. The more information the taxpayer has on the usefulness of taxes and the better the taxpayer's understanding of taxes, the more obedient the taxpayer to settle his tax obligations.

\subsubsection{LEVEL OF EDUCATION}

Educated taxpayers may be aware of non-compliance opportunities. However, their potentially better understanding of the tax system and their higher moral development level promotes a more favourable taxpayer attitude. Therefore greater compliance argues Chan et al. (2012). Cuccia (2013) also suggests that those with a higher education level are more likely to have a higher level of moral development and higher-level attitudes toward compliance and will tend to comply more. One of the measures to increase voluntary compliance is by assuring that taxpayers have a certain level of qualifications, ability, and confidence to exercise their tax responsibility (Mohani, 2012). According to Cuccia (2013), an essential factor affecting tax knowledge is the level of education. Their studies were based in Sudan. They contended that people with higher education levels could easily understand the tax requirement. lyoke (2016), from her studies in Nigeria, also supported that education level influences tax knowledge.

However, Atawadi (2012) refutes that level of education increases tax knowledge. This was based on his studies in Taiwan. He contested that SMEs have tax knowledge despite their low education level. On a similar note, Bird (2014) also argues that taxpayers' education level has been sorely neglected. However, the SMEs were complying with tax regulations. Baru (2016) also seconded that the level of education is not necessary to have tax knowledge, but the taxpayer's beliefs. Her studies were explored in Israel, where most people believe that paying tax is a fraud on its own. This perspective was supported by Mohd et al. (2013) using the religiosity model, where he contended that paying tax is an offence in their religion. Tax knowledge also is not related to the level of education, according to Nellen (2014). She concluded this in a survey conducted on the level of 
education on SMEs. They comply with tax laws in London. Her outcomes presented that even people with a low level of education had a better understanding of tax. On a similar note, Medley (2015) perpetuated that highly educated SME owners in Ghana still did not have tax knowledge and did not comply.

\subsubsection{COMPLEXITY OF TAX LAW}

Tax complexity arises due to the tax law's increased sophistication, argued Richardson and Sawyer (2014). Tax complexity can take many forms such as computational complexity, forms complexity (Bird, 2014), compliance complexity, rule complexity (Carnes and Cuccia, 2011), procedural complexity (Cox \& Eger, 2013), and low level of readability (Pau et al., 2015; Richardson \& Sawyer, 2014).

Complex tax laws and high tax rates, and lack of tax education are the most crucial factors causing non-compliance among SMEs Atawodi and Ojeka (2012). Cuccia (2013) argued that "the complexity of some tax policies causes many people to ignore tax issues; other factors like lack of education only affect tax compliance among SMEs only to a lesser extent." The income tax system was also perceived as inherently complex (Saad, 2013), who further argues that the enormous amount of paperwork to be completed in complying with tax obligations further escalated the problem and encouraged non-compliance among SMEs.

Navigating through the legal and procedural issues related to taxation is often taxing in itself. In many countries, several forms need to be completed, and detailed records need to be kept, argues Maingot and Zeghal (2011). Substantial knowledge about the procedural aspects of tax laws is required. This is particularly challenging since tax laws tend to be changed frequently (Chittenden et al., 2012) and more complex and ambiguous than laws in general (Carnes \& Cuccia, 2012). Tax laws are often too complex to be understood by non-professionals (Kirchler, 2014), which many small business owners undoubtedly are. Also, tax practitioners acknowledge that taxation's complexity makes compliance especially difficult to achieve for many small businesses (Cuccia, 2013).

\subsection{THEORETICAL REVIEW}

The theoretical approaches of tax compliance have commonly been divided into economic deterrence theory and the more comprehensive behavioural theory (Frey \& Feld, 2002). The behavioural theory encompassed the social and fiscal psychological theories. The deterrence theory model was mainly prevalent in examining tax evasion (Frey \& Feld, 2002:7). The theory can be achieved through many approaches, and these could be both punitive and persuasive. In the use of the deterrence theory's punitive nature, it can take the form of increasing the probability of being detected and increasing the tax rate or through the imposition of harsher penalties. It can also take the form of providing better taxpayer education and increased advertising of incentives in instances of being compliant (Frey \& Feld, 2002:7; Sandmo, 2004:7; Feld, Schmidt \& Schneider, 2007:1).

\subsubsection{DETERRENCE THEORY}

This theory emphasizes incentives. The theory suggests that taxpayers are amoral utility maximizers influenced by economic motives such as profit maximization and detection probability. Hence, the taxpayers analyze alternative compliance paths, for instance, whether or not to evade tax, the likelihood of being detected, and the resulting 
repercussions, and then select the alternative way that maximizes their expected after-tax returns after adjusting for risk. Therefore, according to the theory, to improve compliance, penalties for non-compliance should be increased. Thus, there is a positive theoretical relationship between tax penalty and tax compliance. An increase in tax penalty would lead to an increase in tax compliance and vice versa. This research work fell under Deterrence Theory as it looked into the relationship between tax knowledge and tax compliance.

\subsubsection{PSYCHOLOGY THEORY}

Psychology theory posits that taxpayers are influenced to comply with their tax obligations by psychological factors. It focuses on the taxpayers' morals and ethics. The theory suggests that a taxpayer may comply even when the probability of detection is low. As opposed to the deterrence theory that emphasizes increased penalty as a solution to compliance issues, psychology theory emphasizes changing individual attitudes towards tax systems. Thus, one instrument of changing taxpayers' attitude to tax matters is tax education. It is assumed that improved tax education would increase tax compliance and vice versa.

\subsection{EMPIRICAL REVIEW}

Wadesango and Mwandambira (2018), in their study, was to evaluate if lack of tax knowledge contributed to high levels of tax non-compliance amongst SMEs in Zimbabwe, of which a quantitative research approach was used involving a sample of 35 SMEs and 40 tax officials. The findings were that SMEs in Zimbabwe possess basic tax knowledge about taxation but lack a more profound understanding of the difference between presumptive taxation and income-based taxation. However, this insignificantly influences their non-compliance behaviour. It emerged that in order for tax knowledge to influence tax compliance positively, the tax rates and corruption need to be addressed too. Despite these results, ZIMRA should still raise awareness to be uninformed and inexperienced SMEs on the benefits of paying tax and encourage proper record keeping through taxpayer education and social media campaigns.

Cechovsky (2018) asserted that tax avoidance and tax evasion are frequently discussed topics on both a national and European level. Education could play an essential role in fostering tax compliance. This was especially the case in vocational business education. Students were equipped with the knowledge to found a company, and tax-related issues are of importance. As a part of sound economic literacy, tax literacy comprises knowledge and other dimensions, such as attitudes. The focus of his paper was on general tax knowledge and tax compliance attitudes.

Consequently, the primary goals were to present the descriptive results on the students' tax knowledge and attitudes from business colleges in Austria and analyze the relationships between knowledge and tax compliance attitudes. A mixed-method approach that integrates an interview study $(n=22)$ and a questionnaire study $(n=688)$ was applied among the students from the fourth grade of business colleges in Austria. The results give insight into common misconceptions in taxes, which serve as an essential input for instruction. Additionally, knowledge was positively related to a voluntary tax compliance attitude and negatively related to a tax evasion attitude. This indicates that knowledge is an essential factor for tax compliance 
Asrinanda (2018) examined the influence of tax knowledge, self-assessment system, and tax awareness on taxpayer compliance in Banda Aceh City. The sampling technique used was simple random sampling that is simple random sampling. He obtained a sample of 100 respondents. Knowledge taxation, self-assessment, and tax awareness simultaneously and partially significantly affect Banda Aceh City's taxpayer compliance. Variation of taxation knowledge, self-assessment system, and tax awareness affect the taxpayer compliance variation of 93.1 percent. The rest of the 6.9 percent are influenced by other variables outside this research model. In improving taxpayer compliance within Banda Aceh City, the government must socialize the importance of taxes for development to create awareness of taxation and public knowledge in paying taxes.

Fauziati et al. (2016) investigated the impact of tax knowledge on tax compliance. The survey research design was used in conducting the investigation. The primary data source was used, and three hundred (300) copies of the self-administered questionnaire were distributed. The questionnaire's number completed and returned was two hundred and thirty-seven (237), constituting a 79\% response rate. The simple linear regression models were used to estimate the relationship between tax knowledge and tax compliance. The t-statistics were used to test the significance of the study variables. It was revealed that; tax knowledge has no impact on tax compliance. It was therefore recommended that efforts be made to improve the taxpayers' knowledge to improve tax compliance and consequently improve government revenue generation

Modugu and Omoye (2014) appraised the evasion of personal income tax in Nigeria using primary data obtained through the administration of 160 questionnaires to some selected self-employed individuals in Edo State comprising people in business, contractors, professional practitioners like lawyers, doctors, accountants, architects and traders in shops as well as the staff of Federal Inland Revenue Service in Benin City, Edo State, Nigeria. The study used the Spearman rank correlation due to the qualitative nature of the data. The result revealed that the taxpayers' relationship with the tax authority and weak penalties significantly influences tax evasion in Nigeria. Tax rate showed a positive relationship with tax evasion. This means that the higher the tax rate, the higher the tendency of tax evasion. The study recommends that tax authorities intensify taxpayer education and maintain a harmonious relationship capable of fostering voluntary compliance. Also, efforts should be made towards entrenching stiff penalties for evaders. Finally, the prevailing tax rates should be reviewed optimally as not to serve as disincentives to compliance.

Saad (2014) examined taxpayers' views on their level of tax knowledge and perceived complexity of the income tax system. Further, the study attempted to delve into the underlying reasons for non-compliance. Data was gathered through telephone interviews with thirty participants and analyzed using thematic analysis. Results suggest that taxpayers have the inadequate technical knowledge and perceive the tax system as complex. Tax knowledge and tax complexity are viewed as contributing factors towards non-compliance behaviour among taxpayers.

Kofar-Wambai and Hanga (2013) examined the causes of tax evasion in Kano state and the appropriate approach to tackling such causes. The survey method was used to administer a questionnaire of 40 respondents to generate data which is measured by a simple majority or percentage of opinions. It was discovered that informality is a selfreported lack of tax compliance in a sample of individuals and businesses who also answered questions on a large set of issues. The study found that more tax compliance is 
significantly associated with the adequate campaign and judicious tax funds utilization. The authors recommend that the tax base be expanded to bring the hidden economy into the tax net. The tax law shall also be simplified to get rid of ambiguity in the interpretation of its provisions.

Ibadin and Eiya (2013) examined tax evasion and tax avoidance behaviour of the selfemployed, using some selected states in the Nigerian geo-political zone. The study attempts to ascertain the ethical view, educational attainment, tax administration mode, religion, and cultural practices and how these variables affect tax evasion and tax avoidance decisions of the self-employed. The authors employ the statistical tools of ANOVA and Ordinary Least Square (OLS) method of regression to estimate the difference in means of the sampled groups in each geo-political zone and relationships between tax evasion and avoidance and the independent variables. Results reveal that respondents agree that tax evasion is ethical sometimes. A significant relationship exists between the ethical view, mode of tax administration and cultural practices of self-employed and tax evasion and avoidance. The authors recommend that authorities should constantly review tax rates to reflect prevailing economic realities, make tax laws and procedures less technical, and ensure that necessary assistance is provided at all times.

\subsection{RESEARCH METHODS}

This study adopted the survey research design to elicit responses from selected taxpayers in the Ikeja Lagos State of Nigeria to find what they perceived as the relationship between tax knowledge and tax compliance. Primary data was collected through a designed questionnaire and was administered using the Kaiser-Meyer-Olkin test. Cronbach Alpha was also used in establishing the sampling adequacy and reliability of the research instrument. The research statements assessed tax knowledge regarding taxpayer general responsibilities/rights and type of penalties and offences. In contrast, tax compliance was assessed based on compliance with the filing of tax returns and payment.

The survey results were collected from 200 respondents in three categories in Lagos State with 190 valid responses, including self-employed, taxpayers in public and private establishments in Ikeja from October to November 2020. The study adopted a judgemental sampling technique. The choice of Ikeja arose being the capital of Lagos State and the avenue to access the categories of respondents essential for assessing the nature of the relationship between tax knowledge and tax compliance in Lagos State. The data extracted from the questionnaires were analyzed using appropriate descriptive and inferential statistics.

\subsection{DATA PRESENTATION AND ANALYSIS}

Table 1 showed the sample's descriptive, with males constituting $82 \%$ while female constitutes $18 \%$. The majority of the respondents were within the age bracket of 46 years and above. The category constitutes about $63 \%$ of the total respondents. Most of the respondents had a first degree, with $75 \%$ holding a Bachelor's degree and $17 \%$ holding an MBA/M.Sc. The majority of the respondents are self-employed jobs as they constitute $82 \%$, while Private/Partner constitutes $17 \%$. Most of the respondents (30\%) earned an average monthly income between $\$ 200,000$ and $\$ 300,000$, while $18 \%$ earned between $\$ 100,000$ - $\$ 200,000$. This implies that the majority of the respondents belonged to the middle-income category. 
Table 1. Descriptive Statistics

\begin{tabular}{llll}
\hline Descriptive & Categories & Number & $\%$ \\
\hline Gender & Male & 155 & 82 \\
& Female & 35 & 18 \\
& Total & $\mathbf{1 9 0}$ & $\mathbf{1 0 0}$ \\
\hline Age Bracket & $18-25$ years & 2 & 1 \\
& $36-45$ years & 40 & 21 \\
& 46 years and above & 120 & 63 \\
& Total & $\mathbf{1 9 0}$ & $\mathbf{1 0 0}$ \\
\hline Level of Education & PhD & - & - \\
& MBA/M.Sc & 32 & 17 \\
& HND/B.Sc & 142 & 75 \\
& Certificate/Diploma & 15 & 8 \\
& Total & $\mathbf{1 9 0}$ & $\mathbf{1 0 0}$ \\
\hline Who is your current employer & Self Employed & 155 & 82 \\
& Private/Partner & 32 & 17 \\
& Others specify & 3 & 2 \\
& Total & $\mathbf{1 9 0}$ & $\mathbf{1 0 0}$ \\
\hline Gross Monthly Income & Less than N100,000 & 25 & 13 \\
& More than N100,000 but Less than N200,000 & 34 & 18 \\
& More than N200,000 but Less than N300,000 & 57 & 30 \\
& More than N300,000 but Less than N400,000 & 21 & 11 \\
& More than N400,000 but Less than N500,000 & 21 & 11 \\
& Above N500,000 & 32 & 17 \\
& Total & $\mathbf{1 9 0}$ & $\mathbf{1 0 0}$ \\
\hline Who prepared your direct & Myself & 96 & 51 \\
assessment tax return & Tax Consultant & 61 & 32 \\
& Tax Officer & 32 & 17 \\
& Total & $\mathbf{1 9 0}$ & $\mathbf{1 0 0}$ \\
\hline Have you ever been audited by & Yes & 167 & 88 \\
LIRS & No & 23 & 12 \\
& Total & $\mathbf{1 9 0}$ & $\mathbf{1 0 0}$ \\
\hline & & &
\end{tabular}

Regarding the preparation of tax returns, most of the respondents $(51 \%)$ prepared their tax assessments without consulting anybody. In comparison, $32 \%$ enjoy a tax consultant's service, and most of them file their tax returns regularly. For sampling adequacy and reliability, the Kaiser-Meyer-Olkin test (table 2) showed a good result. It revealed that the sample size used for the study is adequate. At the same time, Cronbach's Alpha confirms the internal consistency of the research instrument.

Table 2. Kaiser-Meyer-Olkin Result

\begin{tabular}{lll}
\hline Measurements & KMO Value & Sig. \\
\hline Taxpayer general responsibilities and rights & 0.896 & 0.000 \\
Tax awareness on offences, penalty, and compound & 0.784 & 0.000 \\
Tax compliance with tax payment & 0.758 & 0.000 \\
Tax compliance with filing of returns & 0.708 & 0.000 \\
\hline
\end{tabular}

Table 2 revealed the results of $\mathrm{KMO}$ for each measure in the model, and the result showed an average of 0.8 , which is an acceptable $\mathrm{KMO}$ value. This implies that the sample size used in this study is sufficient for further analysis.

Table 3. Reliability Statistics

\begin{tabular}{lc}
\hline Cronbach's Alpha & N of Items \\
\hline .994 & 32 \\
\hline
\end{tabular}


Table 3 revealed the test result for the research instrument's internal consistency in terms of closeness of the set of items in the questionnaire as a group. The Cronbach's Alpha coefficient of 0.994 implies that the research instrument items have relatively high internal consistency.

The majority of the respondents are fully aware of their responsibilities/rights as taxpayers. They are always informed and declare their actual income received from all sources to the LIRS. They keep records/documents about income and expenditure for six years after submission of the tax return while paying the taxes due within 14 days from the date of issue of the notice of assessment or within the stipulated time. Likewise, they are aware of the penalties for late annual filing or making incorrect returns and false statements, as well as the penalty for late submission of the assessment.

Similarly, the majority of respondents opined that they comply with tax laws because tax authority is intolerant towards evasion punishment or has enough capability to investigate all income or efficiently treat taxpayer correspondence. Similarly, they comply with tax payments because the government spends a significant proportion on welfare. They can enjoy government services, facilities, and infrastructure for which they are grateful.

However, they will not comply with tax return filling once the enforcement is feeble or the penalty is lower than tax saving derived for not comply with tax laws. Similarly, they will not comply with tax return filling once expenditure exceeds income. The price of basic needs kept on increasing. They will also not comply once their friend, parents, and relatives have never been penalized.

Table 4. Test Of Hypothesis - Inferential Statistics

\begin{tabular}{llccc}
\hline & Tax Knowledge & Tax Payment & Filling of Return \\
\hline Tax Knowledge & Pearson Correlation & 1 & $.993^{* *}$ & $.986^{* *}$ \\
& Sig. (2-tailed) & & 0 & 0 \\
& $\mathrm{~N}$ & 190 & 190 & 190 \\
Tax Payment & Pearson Correlation & $.993^{\star *}$ & 1 & $.995^{\star *}$ \\
& Sig. (2-tailed) & 0 & & 0 \\
& $\mathrm{~N}$ & 190 & 190 & 190 \\
Filling of Return & Pearson Correlation & $.986^{* *}$ & $.995^{* *}$ & 1 \\
& Sig. (2-tailed) & 0 & 0 & 190 \\
& $\mathrm{~N}$ & 190 & 190 & \\
\hline
\end{tabular}

**. Correlation is significant at the 0.01 level (2-tailed)

Source: (2021) Author's Computation Using E-views 8

A bivariate correlation was calculated in testing the hypothesized relationships between tax knowledge and the two specified dimensions of tax compliance. The correlation matrix is provided in Table 4 above. The analysis indicates that, as hypothesized, general tax knowledge was significantly related to tax compliance in payment terms $(r=.993, p$ $=0.000)$ and tax compliance in terms of filing of returns $(r=.986, p=0.000)$. Thus, the results revealed that there is a positive relationship between tax knowledge and tax compliance.

\section{DISCUSSION OF FINDINGS}

The relationships between tax knowledge and the two specified tax compliance dimensions of tax payment compliance and filings of annual returns and a bivariate correlation were calculated. The correlation matrix is provided in Table 4 above, and this 
indicated that, as hypothesized, general tax knowledge was significantly related to tax compliance in term of payment $(r=.993, p=0.000)$ and tax compliance in term of filing of returns $(r=.986, p=0.000)$. Thus, the results revealed that there is a positive relationship between tax knowledge and tax compliance. This is evidenced with the result of Cochovsky (2018) where general tax knowledge was significantly related to attitude towards voluntary compliance $(r=.204, p<.01)$ and to attitudes towards tax avoidance $(r$ $=.183, p<.01)$. This finding is the same as the study of Oladipupo \& Obaeze (2016), which stated that tax knowledge (TKNOW) has a significant positive relationship with tax compliance, also the study of Yan, Arokiasamy \& Suat (2010) that opined that tax awareness has to be spread in order to inform all consumers about the direction and objectives the relevant tax authorities wish to achieve by administering taxation policy. However, the tax penalty has an insignificant positive impact on tax compliance.

\section{CONCLUSION AND RECOMMENDATION}

The findings above concluded that there are positive and strong relationships between tax knowledge and the two specified dimensions of tax compliance regarding tax payment and filings of returns. The study concludes that tax knowledge has a positive relationship between tax knowledge and payment of taxes in Lagos state; this implies that Lagosians know tax payment. This is also the same as the relationship between tax knowledge and filings of annual returns in Lagos State, Nigeria. This conclusion is inconsonant with the conclusion of Cochovsky (2018), where general tax knowledge was significantly related to attitude towards voluntary compliance and attitudes towards tax avoidance, Oladipupo and Obaeze (2016) who concluded that that tax knowledge had a significant positive relationship with tax compliance, and Yan, Arokiasamy and Suat (2010).

Although this research work indicated a strong and positive relationship between tax knowledge and tax compliance in Lagos State, Lagos State Internal Revenue Services should not relent in educating taxpayers in the state by creating awareness and advertising the public domains. The reason for this recommendation is to avoid the decline in the revenue base of the state.

\section{REFERENCES}

Adedeji, T. O., \& Oboh, C. S. (2012). An empirical analysis of tax leakages and economic growth in Nigeria. European Journal of Economics, Finance and Administrative Sciences, 48.

Adediran, S. A., Alade, S. O., \& Oshode, A. A. (2013). The impact of tax audit and investigation on revenue generation in Nigeria. European Journals of Business Management, 5(26).

Alm, J., Jackson, B. \& McKee, M. (1992). institutional uncertainty and taxpayer compliance. American Economic Review, 82, 18-26.

Andreoni, J., Erard, B. \& Feinstein, J. (1998). Tax compliance. Journal of Economic Literature, 36, 818-860.

Akintoye, I. R., \& Tashie, G. A. (2013). The effect of tax compliance on economic growth and development in Nigeria. West-Africa. British Journal of Arts and Social Sciences, 2(2), 222-232.

Allingham, M.G. \& Sandmo, A. (1972). Income tax evasion: A theoretical analysis. Journal of Public Economics, 1, 323-338. http://dx.doi.org/10.1016/0047-2727(72)90010-2

Badara, M. S. (2012). The effect of tax audit on tax compliance in Nigeria (A study of Bauchi State Board of Internal Revenue). Research Journal of Finance and Accounting, 3(4), 74-80.

Bahl, R. \& Bird, R. (2008). Tax policy in developing countries: Looking back and forward. National Tax Journal, 297-301. https://doi.org/10.17310/ntj.2008.2.06

Cechovsky, N. (2018). The importance of tax knowledge for tax compliance: A study on the tax literacy of vocational business students. In C. Nägele \& B. E. Stalder (Eds.), Trends in Vocational Education and Training Research. Proceedings of the European Conference on Educational Research (ECER), 113121). https://doi.org/10.5281/zenodo.1319646

Chattopadhyay, S. \& Das-Gupta, A. (2002). The compliance cost of the personal income tax and its determinants. Report to the National Institute of Public Finance and Policy, New Delhi. 
Csontos, L., Kornai, J. \& Tóth, I.G. (1998). Tax awareness and reform of the welfare state: Results of a Hungarian survey. Economics of Transition, 6, 287-312. https://doi.org/10.1111/j.14680351.1998.tb00050.x

Djawadi, B., \& Fahr, R. (2013). The impact of tax knowledge and budget spending influence on tax compliance. IZA Discussion Paper Series. 7255. Bonn: Institute for the Study of Labor.

Doran, M. (2009). Tax Penalties and Tax Compliance: A Personal Income Tax Non-Compliance in Malaysia. PhD Thesis, Victoria University, Melbourne.

Fakile, A.S. (2011). Analysis of Tax Morale and Tax Compliance in Nigeria. PhD Thesis, Covenant University, Otta.

Fauziati, P., Minovia, A.F., Muslim R.Y. \& Nasrah, R. (2016). The impact of tax knowledge on tax compliance case study in Kota Padang, Indonesia. Journal of Advanced Research in Business and Management Studies. 2(1), 22-30

Feld, L.P. \& Frey, B.S. (2007) Tax compliance as the result of a psychological tax contract: The role of incentives and responsive regulation. Law and Policy. 29, 102-120. https://doi.org/10.1111/j.14679930.2007.00248.x

Gberegbe, F. B., \& Umoren, A. O. (2017). The perception of tax fairness and personal income tax compliance of SMEs in rivers state. Journal of Research in Business and Management. 5(2), 40-51.

Gordon, J. (1990). Evading taxes by selling for cash. Oxford Economic Papers. 42, 244-255.

Hasseldine, J., Holland, K. \& Rijt, P.V. (2009). The Management of Tax Knowledge. The Association of Chartered Certified Accountants, ACCA, London.

James, S. \& Alley, C. (2004). Tax compliance, self assessment, and tax administration. Journal of Financial and Management in Public Services. 2, 27-42.

Jemaiyo, B. \& Mutai, G. C. (2016). Determinants of tax compliance and their influence on the level of tax compliance in the real estate sector, Eldoret town-Kenya. African peer-reviewed journal. 12(1), 555-584.

Kirchler, E. (2007). The Economic Psychology of Tax Behavior. Cambridge University Press, Cambridge. https://doi.org/10.1017/CBO9780511628238

Lai, M.L, Zalilawati, Y., Amran, M.M. \& Choong, K.F. (2013) Quest for tax education in non-accounting curriculum: A Malaysia study. Asian Social Science. 9, 154-162. http://dx.doi.org/10.5539/ass.v9n2p154

Loo, E.C. \& Ho, J.K. (2005). Competency of Malaysian salaried individuals in relation to tax compliance under self assessment. Journal of Tax Research, 3, 45-62.

Lumumba, O.M., Migwi, S.W. \& Magutu, O. (2010). Taxpayers' attitudes and tax compliance behavior in kenya: how the taxpayers' attitudes influence compliance behavior among SMEs business income earners. African Journal of Business \& Management, 1, 112-122.

Marrelli, M. \& Martina, R. (1998). Tax evasion and strategic behavior of the firm. Journal of Public Economics, 37, 55-69. https://doi.org/10.1016/0047-2727(88)90004-7

Masud, A., Aliyu, A. A. \& Gambo, J. E (2014). Tax rate and tax compliance in Africa. European Journal of Accounting, Auditing, and Finance Research, 2(3), 22 - 30.

Modugu, K. P., and Anuaduba, J. O. (2014). Impact of tax audit on tax compliance in Nigeria. International Journal of Business and Social Science, 5(9), 207-215.

Mohani, A. (2001). Personal Income Tax Noncompliance in Malaysia. PhD Thesis, Victoria University, Melbourne.

Mukasa, J. (2011). Tax Knowledge, Perceived Tax Fairness, and Tax Compliance in Uganda. Master of Science, Makerere University, Kampala.

Namusonge, G.S., Biraori, O.E. \& Kipicoech, E.C. (2014). Factors affecting tax compliance among small and medium enterprises in Kitale, Kenyan. International Journal of Recent Research in Commerce Economics \& Management, 1, 60-75.

Niemirowski, P. Wearing, A. J. Baldwin, S. Leonard, B. \& Mobbs, C. (2002). The influence of tax-related behaviours, beliefs, attitudes, and values on Australian taxpayer compliance.

Ojo, A., \& Sunmola, O. (2017). Tax Audit and Investigation: Trigger Points and Mitigative Measures. KPMG Advisory Services, Nigeria.

Ojonta, B. A. (2013). Tax Audit and Investigation in Enugu State. Nigeria: University of Nigeria Nsukka.

Okonkwo, A. I. (2014). Critical evaluation of tax audit and investigation processes in enhancing tax compliance: being a paper presented at the CITN MPTP in Uyo on October 8-9.

Oladipupo, A. O., \& Obazee, U. (2016). Tax knowledge, penalties, and tax compliance in small and medium scale enterprises in Nigeria. iBusiness, 8, 1-9. https://doi.org/10.4236/ib.2016.81001

Oloyede F. L., Kupoluyi A. K., Oyedokun, G. E. \& Benjamin, R. D. (2017), Informal sector tax administration and monitoring in Nigeria. Journal of Taxation and Economic Development, 16(2), 16-35.

Onuoha, L. N., \& Dada, S. O. (2016). Tax audit and investigation as imperatives for efficient tax administration in Nigeria. Journal of Business Administration and Management Sciences Research, 5(5), 066-076

Palil, M.R. (2010) Tax Knowledge and Tax Compliance Determinants in Self Assessment System in Malaysia. PhD Thesis, University of Birmingham, Birmingham. 
Palil, M. R., \& Mustapha, A. F. (2011) Tax audit and tax compliance in Asia: A case study of Malaysia. European Journal of Social Sciences, 24(1), 7-32.

Richardson, G. (2006). Determinants of tax evasion: A cross country investigation. Journal of International Accounting, Auditing, and Taxation, 15, 150-169. https://doi.org/10.1016/j.intaccaudtax.2006.08.005

Saad, N. (2012). Perception of tax fairness and tax compliance behavior: A Comparative Study. Jurnal Pengurusan, 36, 89-100.

Saad N. (2014). Tax knowledge, tax complexity and tax compliance: Taxpayers' view. Procedia - Social and Behavioral Sciences 109, 1069 - 1075. https://doi.org/10.1016/j.sbspro.2013.12.590

Saira, K., Zariyawati, M.A. \& Yoke-May, L. (2010) An exploratory study of goods and services tax awareness in Malaysia. Seminar on National Resilience (SNAR), Political Management and Policies in Malaysia. 13-15

Singh, V. \& Bhupalan, R. (2001). The Malaysian self assessment system of taxation: Issues and challenges. Tax National, 12-17.

Slemrod, J. (2000). Why People Pay. Taxes: Tax Compliance and Enforcement, Ann Arbor, University of Michigan Press. 1-8.

Soyemi, K. A. (2014). Auditing and Assurance Services. Abeokuta: Lek Silicon Publishing Company Ltd

Soyinka, K. A., Jinadu, O., \& Sunday, O. M. (2016). Tax audit determinants and corporate tax compliance in Nigeria. The International Journal of Business \& Management, 4(5), 95-99.

Virmani, A. (1989). Indirect tax evasion and production efficiency. Journal of Public Economics, 39, 223-237. https://doi.org/10.1016/0047-2727(89)90041-8

Wadesango Newman (2018). Evaluating the impact of tax knowledge on tax compliance among small medium enterprises in a developing country. Academy of Accounting and Financial Studies Journal, 22,(6), 15282635-22-6-302,

Wang, L. \& Conant, J. (1988). Corporate tax evasion and output decision of the uncertain monopolist. National Tax Journal, 41, 579-581.

Yan, M. C. K., Arokiasamy, L., \& Suat, C. L. A. (2010). Indirect taxation: Awareness and impact on undergraduates. International Research Journal of Finance and Economics, 41, 43-50. 